3. Edler I, Hertz CH. The use of ultrasonic reflectoscope for the continuous recording of the movements of heart walls. 1954. Clin Physiol Funct Imaging. 2004;24:118-36

4. Yoshida T, Mori M, Nimura Y, Hikita G, Taka Gishi S, Nakanishi K, et al. Analysis of heart motion with ultrasonic Doppler method and its clinical application. Am Heart J. 1961;61:61-75.

5. Zaret BL, Strauss HW, Martin ND, Wells HP Jr, Flamm MD Jr. Noninvasive regional myocardial perfusion with radioactive potassium. Study of patients at rest, with exercise and during angina pectoris. N Engl J Med. 1973; 288:809-12.

6. Lebowitz E, Greene MW, Fairchild R, Bradley-Moore PR, Atkins HL, Ansari AN, et al. Thallium-201 for medical use. I. J Nucl Med. 1975;16:151-5.

7. Pohost GM, Zir LM, Moore RH, McKusick KA, Guiney TE, Beller GA. Differentiation of transiently ischemic from infarcted myocardium by serial imaging after a single dose of thallium-201. Circulation. 1977:55:294-302.

8. Goldman MR, Brady TJ, Pykett IL, Burt CT, Buonanno FS, Kistler JP, et al. Quantification of experimental myocardial infarction using nuclear magnetic resonance imaging and paramagnetic ion contrast enhancement in excised canine hearts. Circulation. 1982;66:1012-6.

9. Buonanno FS, Pykett IL, Brady TJ, Pohost GM. Clinical applications of nuclear magnetic resonance (NMR). Dis Mon. 1983;29:1-81.
10. Ratner AV, Okada RD, Newell JB, Pohost GM. The relationship between proton nuclear magnetic resonance relaxation parameters and myocardial perfusion with acute coronary arterial occlusion and reperfusion. Circulation. 1985;71:823-8.

11. Abdulla J, Abildstrom SZ, Gotzsche O, Christensen E, Kober L, TorpPedersen C. 64-multislice detector computed tomography coronary angiography as potential alternative to conventional coronary angiography: a systematic review and meta-analysis. Eur Heart J. 2007;28:3042-50.

12. Gopalakrishnan P, Wilson GT, Tak T. Accuracy of multislice computed tomog raphy coronary angiography: a pooled estimate. Cardiol Rev. 2008;16:189-96.

13. Fatehi Hassanabad A, Garcia J, Verma S, White JA, Fedak PWM. Utilizing wall shear stress as a clinical biomarker for bicuspid valve-associated aortopathy Curr Opin Cardiol. 2019;34:124-31.

14. Farooqi KM, Mahmood F. Innovations in preoperative planning: insights into another dimension using 3D printing for cardiac disease. J Cardiothorac Vasc Anesth. 2018;32:1937-45

15. Hadeed K, Acar P, Dulac Y, Cuttone F, Alacoque X, Karsenty C. Cardiac 3D printing for better understanding of congenital heart disease. Arch Cardiovasc Dis. 2018;111:1-4.

16. Oberoi M, Foley TA, Schaff HV. Hypertrophic cardiomyopathy: interactive 3-dimensional modeling of phenotypic variants. J Thorac Cardiovasc Surg. 2022;163:e243-5.

\section{Commentary: Prevention of incomplete resection during septal myectomy: Virtual seeing is actual believing}

\author{
Edward Buratto, MBBS, PhD, ${ }^{\mathrm{a}, \mathrm{b}, \mathrm{c}}$ and \\ Igor E. Konstantinov, MD, PhD, FRACS ${ }^{\mathrm{a}, \mathrm{b}, \mathrm{c}, \mathrm{d}}$
}

Extended myectomy is the gold standard for treating hypertrophic obstructive cardiomyopathy (HOCM), and it can be achieved with low complication rates in high-volume institutions. ${ }^{1-5}$ Of interest, recurrent obstruction is rare in such

\footnotetext{
From the ${ }^{\text {a}}$ Department of Cardiac Surgery, Royal Children's Hospital, Melbourne, Australia; 'bepartment of Paediatrics, University of Melbourne, Melbourne, Australia; 'Heart Research Group, Murdoch Children's Research Institute, Melbourne, Australia; and ${ }^{\mathrm{d}}$ Melbourne Centre for Cardiovascular Genomics and Regenerative Medicine, Melbourne, Australia.

Disclosures: The authors reported no conflicts of interest.

The Journal policy requires editors and reviewers to disclose conflicts of interest and to decline handling or reviewing manuscripts for which they may have a conflict of interest. The editors and reviewers of this article have no conflicts of interest.

Received for publication Jan 14, 2021; revisions received Jan 14, 2021; accepted for publication Jan 14, 2021; available ahead of print Jan 20, 2021.

Address for reprints: Igor E. Konstantinov, MD, PhD, FRACS, Royal Children's Hospital, Flemington Rd, Parkville 3052, Australia (E-mail: igor.konstantinov@rch. org.au).

J Thorac Cardiovasc Surg 2022;163:e248-50

$0022-5223 / \$ 36.00$

Crown Copyright $\subset 2021$ Published by Elsevier Inc. on behalf of The American Association for Thoracic Surgery

http://dx.doi.org/10.1016/j.jtcvs.2021.01.052
}

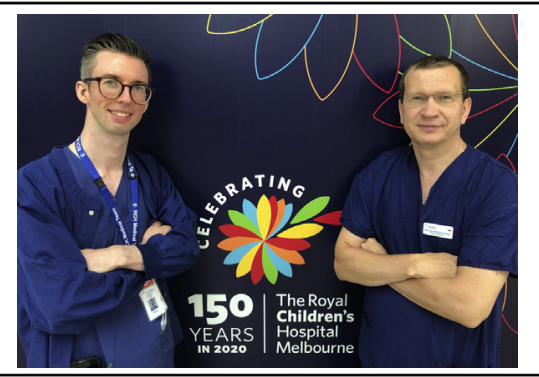

Edward Buratto, MBBS, PhD, and Igor E. Konstantinov, MD, PhD, FRACS, at the Royal Children's Hospital, Melbourne.

CENTRAL MESSAGE

The depth, length, and width of septal myectomy are all important to prevent residual obstruction.

high-volume institutions. ${ }^{1-5}$ It is becoming increasingly apparent that the vast majority of so-called "recurrences" are in fact consequences of incomplete initial resection. Conversely, excessive resection may result in conduction abnormalities and iatrogenic ventricular septal defects. ${ }^{2}$ The matter is further complicated by the variable morphology of HOCM and the relative scarcity of these patients at many institutions. Traditionally, septal morphology is assessed primarily with 2-dimensional (2D) echocardiography, with magnetic resonance imaging used in selected cases. 

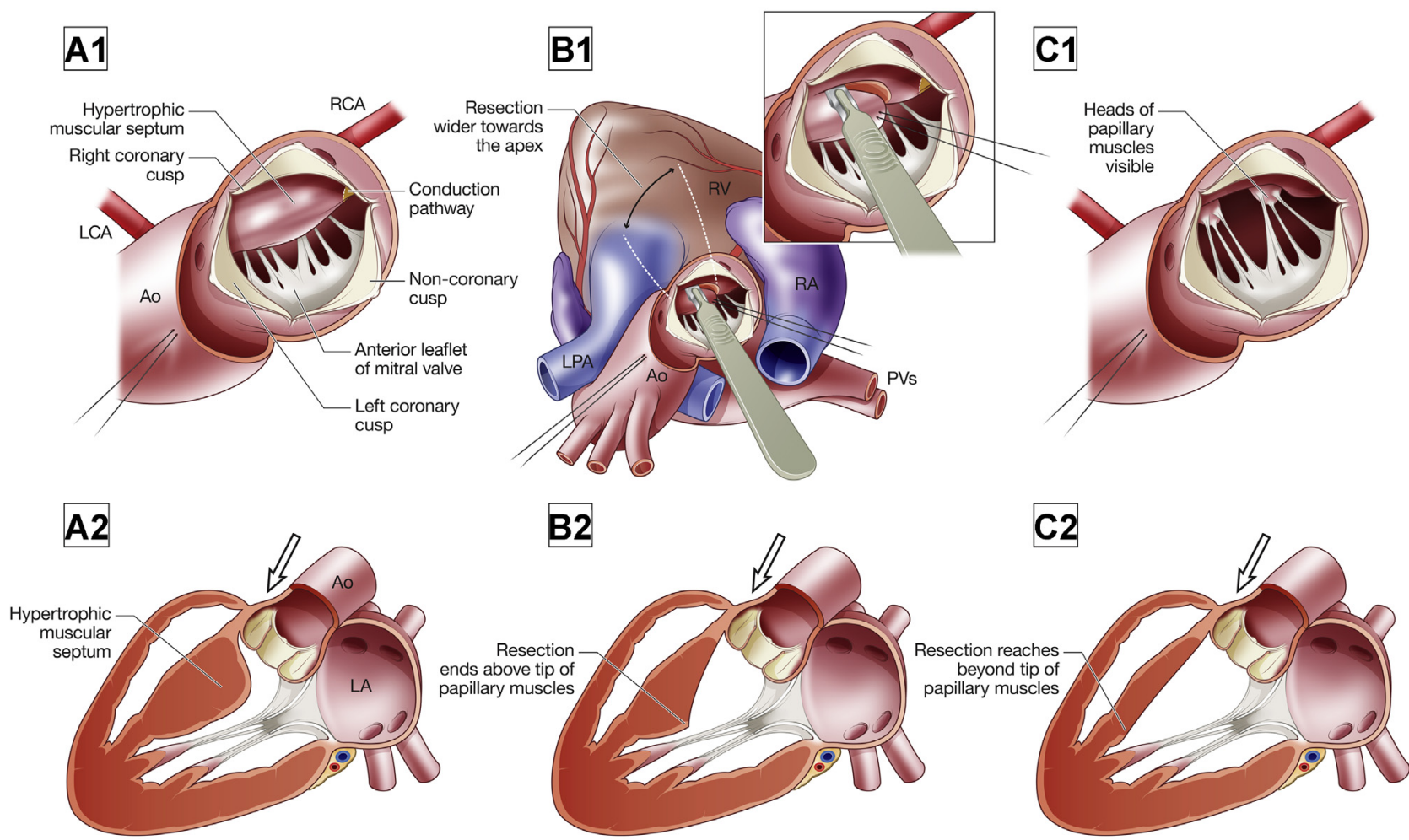

FIGURE 1. Pitfalls of incomplete resection. Intraoperative view of the left ventricular cavity during transaortic septal myectomy is obscured (A1). The surgical view (arrow) allows clear visualization of only the "tip of the iceberg" (A2). In as much as surgical blade is directed toward the apex of the left ventricle (B1), the width, depth, and length of resection may be underappreciated, resulting in intracavitary residual obstruction due to incomplete resection (B2). With proper resection, good visualization of the papillary muscle should be achieved (C and $\mathrm{C} 1)$. RCA, Right coronary artery; $L C A$, left coronary artery; $A o$, aorta; $R V$, right ventricle; $R A$, right atrium; $L P A$, left pulmonary artery; $P V s$, pulmonary veins.

More recently, 3-dimensional (3D) computed tomography (CT) has emerged as a useful tool for precise delineation of septal and ventricular anatomy. ${ }^{6}$ The left ventricular outflow tract is a complex $3 \mathrm{D}$ structure, and the $2 \mathrm{D}$ slices provided by traditional imaging methods might not provide adequate information for accurately planning septal myectomy.

Extensive experience with septal myectomy has been accumulated by the Mayo Clinic. ${ }^{2-4}$ In this issue of the Journal, the Mayo Clinic team describes a novel interactive tool for preoperative assessment of the left ventricular outflow tract in patients with $\mathrm{HOCM}^{7}$ Using multiphasic cardiac CT scans and easily accessible interactive software, they were able to generate $3 \mathrm{D}$ models of the heart for precise diagnosis and preoperative planning. The model could subsequently be exported as an interactive PDF file or printed using a 3D printer. This technique has the potential to simplify preoperative planning, making it easier for the surgeon to visualize the extent of muscle needing to be resected, and as such, it could be particularly helpful in children, who may require a more extensive ventriculoseptoplasty for bilateral obstruction. ${ }^{8,9}$ This approach also could be helpful for assessing recurrent obstruction, which is very rare. ${ }^{10}$ Furthermore, abnormalities of accessory papillary muscle that are often not clearly identified on conventional imaging ${ }^{11}$ could be properly assessed for preoperative planning.

As the view of the septal area is naturally obscured (Figure 1, Al) and the surgeon in fact sees only the "tip of the iceberg" (Figure 1, A2), the importance of preoperative virtual visualization and thorough planning cannot be overemphasized. ${ }^{12}$ The natural tendency to resect only visible septum (Figure 1, B1) would result in incomplete resection in most cases (Figure 1, B2). Because width (Figure 1, B1 and $C 1$ ), length, and depth (Figure 1, C2) of the septal myectomy are all equally important to achieve complete relief of obstruction, preoperative appreciation of the 3D spatial anatomy is crucial. Achieving the appropriate depth, length, and width in septal myectomy is the key to success. Virtual seeing is believing!

\section{References}

1. Hodges K, Rivas CG, Aguilera J, Borden R, Alashi A, Blackstone EH, et al. Surgical management of left ventricular outflow tract obstruction in a specialized hypertrophic obstructive cardiomyopathy center. J Thorac Cardiovasc Surg. 2019;157 2289-99. 
2. Kotkar KD, Said SM, Dearani JA, Schaff HV. Hypertrophic obstructive cardiomyopathy: the Mayo Clinic experience. Ann Cardiothorac Surg. 2017;6: 329-36.

3. Nguyen A, Schaff HV, Hang D, Nishimura RA, Geske JB, Dearani JA, et al. Surgical myectomy versus alcohol septal ablation for obstructive hypertrophic cardiomyopathy: a propensity score-matched cohort. J Thorac Cardiovasc Surg. 2019; 157:306-15.e3.

4. Maron BJ, Dearani JA, Ommen SR, Maron MS, Schaff HV, Nishimura RA, et al Low operative mortality achieved with surgical septal myectomy: role of dedicated hypertrophic cardiomyopathy centers in the management of dynamic subaortic obstruction. J Am Coll Cardiol. 2015;66:1307-8.

5. Ommen SR, Mital S, Burke MA, Day SM, Deswal A, Elliott P, et al. 2020 AHA/ ACC guideline for the diagnosis and treatment of patients with hypertrophic cardiomyopathy: executive summary: a report of the American College of Cardiology/American Heart Association joint committee on clinical practice guidelines. J Am Coll Cardiol. 2020;76:3022-55.

6. Takayama H, Yu SN, Sorabella R, Leb J, Pulerwitz TC, Cooper C, et al. Virtual septal myectomy for preoperative planning in hypertrophic cardiomyopathy. $J$ Thorac Cardiovasc Surg. 2019;158:455-63.
7. Oberoi M, Foley TA, Schaff HV. Hypertophic cardiomyopathy: interactive 3dimensional modelling of phenotypic variants. J Thorac Cardiovasc Surg. 2022;163:e243-5.

8. Laredo M, Khraiche D, Raisky O, Gaudin R, Bajolle F, Maltret A, et al. Long-term results of the modified Konno procedure in high-risk children with obstructive hypertrophic cardiomyopathy. J Thorac Cardiovasc Surg. 2018;156:2285-94.e2.

9. Quintana E, Johnson JN, Rotes AS, Cetta F, Ommen SR, Schaff HV, et al. Surgery for biventricular obstruction in hypertrophic cardiomyopathy in children and young adults: technique and outcomes. Eur J Cardiothorac Surg. 2015;47:1006-12.

10. Cho YH, Quintana E, Schaff HV, Nishimura RA, Dearani JA, Abel MD, et al. Residual and recurrent gradients after septal myectomy for hypertrophic cardiomyopathy - mechanisms of obstruction and outcomes of reoperation. $J$ Thorac Cardiovas Surg. 2014;148:909-15; discussion 915-6.

11. Lentz Carvalho J, Schaff HV, Morris CS, Nishimura RA, Ommen SR, Maleszewski JJ, et al. Anomalous papillary muscles - implications in the surgical treatment of hypertrophic obstructive cardiomyopathy. J Thorac Cardiovasc Surg. 2022;163:83-9.e1

12. Williams WG, Konstantinov IE. Subaortic myectomy for patients with hypertrophic obstructed cardiomyopathy. Op Tech Thorac Cardiovasc Surg. 2004;9:254-60. 